\title{
From daily land-use practice to global phenomenon. On the origin and recent evolution of prosecco's wine landscape (Italy)
}

Abstract

In recent years Prosecco, the renowned Italian sparkling wine, has become an increasingly popular product globally, leading to a massive expansion of viticulture within Prosecco's production zones (north-eastern Italy).

Through qualitative and quantitative methods, this paper provides the first empirical analysis of the landscape and land-use modifications generated by the planting of new vineyards. Specifically, it seeks to reconstruct both the long-term historical factors that brought about the emergence of the specific winescape (today a candidate for becoming a UNESCO World Heritage Site), and the recent conversion of croplands, grassland, and woodland to wine-growing areas. The landscape, particularly on the plains, is radically changing due to the new, large geometric plantations that are perfectly suited to mechanical viticulture.

This paper's conclusions argue for overall regulation of such a booming monoculture in order to effectively harmonize the production needs of wine-growers with the needs of other land-uses (mostly residential), and to protect the historical landscape patterns and ecological biodiversity.

Keywords

Prosecco • north-eastern Italy $\cdot$ semi-structured interviews $\bullet$ GIS analysis

- proseccosization $\cdot$ regulation

(C) University of Warsaw - Faculty of Geography and Regional Studies

\section{Introduction}

This paper presents the results of a case study conducted by the author in an area $50 \mathrm{~km}$ north of Venice (north-eastern Italy), where the globally famous Prosecco sparkling wine is produced. Its aim is to provide empirical evidence for the landscape and land-use modifications generated by the recent major expansion in viticulture, which has resulted from a growing demand for Prosecco, especially on international markets.

National and international scientific publications on the Prosecco region are still limited to the economic, agronomic, and chemical-organoleptic aspects of the wine (see, for instance, Tomasi et al. 2013). To date, no attention has been devoted to the specific landscape and land-use changes generated by the intensified use of grape-growing land. At present, this research provides the first in-depth analysis of the phenomenon within the field of planning.

Furthermore, at a more general level, this article seeks to expand the (still little) scientific literature that has specifically taken into consideration the relationship between vineyard expansion and land-use changes. Some relevant contributions ${ }^{1}$ have focused upon the pressures on land resources (land-use changes, landscape and natural habitat degradation, conflicts with local communities, etc.) that have been derived from the decisions taken by grape-producers in order to expand the land available for wine-growing and thus meet the global wine market demand. A reflection on the origin and recent evolution of the Prosecco region, currently one of the most competitive areas in

${ }^{1}$ See, for instance, Merenlender 2000; Fairbanks et al. 2004; Costantini \& Barbetti 2008; Martínez-Casasnovas et al. 2010; Dobos et al. 2014; Mariani \& Vastola 2015; Vinatier \& González Arnaiz 2018; Zambon et al. 2018.
Matteo Basso

Department of Design and Planning in Complex Environments, IUAV University of Venice, Italy e-mail:mbasso@iuav.it

Received: 18 February 2018

Accepted: 24 April 2018

wine production in Italy and Europe, is thus believed to further enrich such research findings and theories.

\section{Methodology}

This study is based on both qualitative and quantitative analyses, that were carried out in parallel between October 2016 and September 2017.

The qualitative research methodology used was based on 29 semi-structured in-depth interviews aimed at collecting information on the history and impact of Prosecco's spatial diffusion. ${ }^{2}$ A significant "sample" of actors who played different roles in the territory was based on reviews from the local press and media along with a snowball approach that led to interviewing people who were referred to by the initial respondents. The sample consisted of two key informants; five experts; seven local representatives of wine-growers, wine-makers, and wineries producing sparkling wine; seven political and technical representatives of public institutions; and eight representatives of associations, committees, and informal groups of citizens.

The quantitative research methodology was based on a GIS processing, mapping, and the interpretation of data regarding land-use changes that occurred in the territory as a result of the expansion of wine-growing areas. Two main institutional data sources were used: Veneto Region Land Cover Map (2007 and

${ }^{2}$ Topics discussed in-depth during the interviews were as follows: the structure of the Prosecco wine industry, the land-use modifications set in motion by grape-producers in order to expand the land available for wine-growing, the perceived environmental effects of such a growing monoculture, and the regulations introduced by policymakers in order to govern such a massive vineyards expansion. 


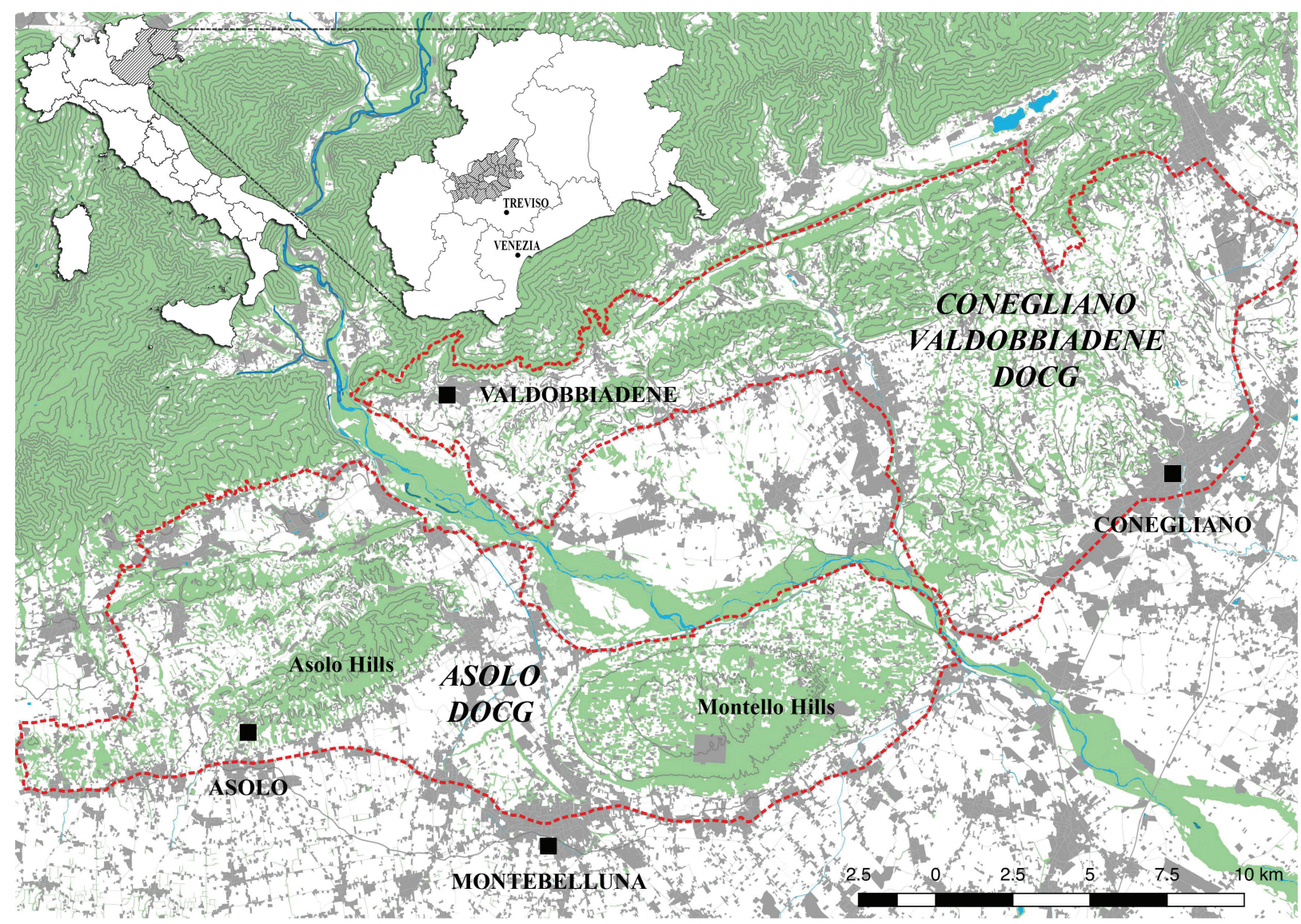

Figure 1. The Prosecco region

Source: author's elaboration

2012 edition), ${ }^{3}$ and the Veneto Region and AVEPA's Venetian Vineyard Register (up-to-dated until the end of 2016), which provides information on the year and size of Glera grape vineyard plantations. $^{4}$

\section{The Prosecco Region}

The internationally famous Prosecco is an Italian white wine made mostly from the Glera grape variety. Today, it is exclusively produced in a vast territory in north-eastern Italy that is organized into three production zones (the Denominations of Origin), each with specific regulations relating to their entire wine production process (viticulture, vinification, the sparkling wine-making process, bottling, etc.). ${ }^{5}$ According to the Ministerial Decree of 17 July 2009 (Ministerial Decree 2009), Prosecco is produced within the following areas (Fig. 1):

1) two historical hillside zones in the Pre-Alps area of the Province of Treviso, $50 \mathrm{~km}$ north of Venice: the Conegliano Valdobbiadene DOCG (former DOC zone, established in 1969), and the Asolo DOCG (former DOC zone, established in 1977):

${ }^{3} \mathrm{~A}$ third edition of the map, which is in the process of being completed by the Veneto Region, is still not available.

${ }^{4}$ Avepa (Agenzia Veneta per i Pagamenti in Agricoltura) is the Veneto Region's ad hoc agency that manages and transfers EU Regional funds to the agricultural sector and regularly updates the Vineyard Register.

${ }^{5}$ The Prosecco's Denominations of Origin are called, according to a hypothetical decreasing scale of quality, DOCG (Denomination of Controlled and Guaranteed Origin), DOC (Denomination of Controlled Origin), and IGT (Typical Geographic Indication). DOCG has more restrictive regulations.
2) a larger DOC zone that stretches across five provinces in the Veneto Region and the entire Friuli-Venezia Giulia Region.

The analysis focuses specifically on the 15 municipalities that are wholly or partly located within the institutional Conegliano Valdobbiadene DOCG zone. ${ }^{6}$ This territory, in the foothills of the Pre-Alps, is a sprawling, low-density, socio-spatial region composed of small towns, villages, historical buildings, and rural and natural areas.

\section{Origins: the historical evolution of a winescape}

According to the European Landscape Convention that was drawn up in 2000 by the Council of Europe, "landscape means an area, as perceived by people, whose character is the result of the action and interaction of natural and/or human factors" (European Landscape Convention of the Council of Europe 2000). The aforementioned definition of landscape places particular attention on the cultural identity of territories, which originates (often unconsciously) in the complex historical relations between nature and human communities in their everyday engagement and land-use practices.

The case of Prosecco is especially interesting from this perspective. Its staggering economic success reflects an age-old process of social construction, where natural, human, cultural,

${ }^{6}$ The DOCG institutional territory was defined on the basis of geomorphological and pedoclimatic analyses, and does not conform to the municipal boundaries. Consequently, a municipality can fall partly within the DOCG zone while the remaining part of its territory is classified as DOC zone (since 2009). 
and socio-economic factors have co-evolved to be eventually supported by ad hoc public policies. ${ }^{7}$ Now famous internationally, this sparkling wine was originally an "anonymous" wine that most families made and consumed themselves. Similarly, winegrowing, currently a fundamental asset within the regional and local economy (Research Centre of the Conegliano Valdobbiadene District 2017; Veneto Region 2017), was simply one of various farming practices. From Braudel's perspective on the longue durée (Braudel 1958), the winescape is a concrete result of events, facts, and evolutions that occur incrementally and repetitively in the short-term, carried out by wine-growers on a daily basis. At the same time, however, a long-term "structure" - an organization, a certain consistency, a rather stable relationship between context and social forces - has endured throughout the generations.

As already mentioned, this vineyard landscape is the result of the interrelation between many factors, as hereafter explained.

\section{Natural factors}

The ways and the timing that have helped the spread of the Glera grape variety - the main grape variety contained in Prosecco wine - across the hills of Conegliano Valdobbiadene is still being debated among scholars. Originally, it probably came from the town that bears its name in the area of Istria and the Karst Plateau near the city of Trieste (Tomasi et al. 2013). ${ }^{8}$ From there, it spread to the Veneto Region, specifically to the hills near Padua (Euganean Hills), Vicenza (Berici Hills) and eventually to the Province of Treviso (the hills of Asolo and Conegliano Valdobbiadene).

Grape cultivation is an age-old tradition in the Conegliano Valdobbiadene area that can be traced to pre-Roman times (7th century B.C.). Without a doubt, these zones offer the optimal setting for the Glera, particularly due to: a) the steep, sunny hills (that guarantee meteoric water drainage); b) the foothills of the Alps, which block cold northerly winds; c) the Venetian lagoon (50 km away), which lets in warm winds; d) a temperate climate with good summer rainfall; and e) alluvial soils. Man's stubborn hand has succeeded in moulding a landscape, a culture, and a tradition on these steep hillslopes - an inhospitable environment for most other agricultural practices (Fig. 2).

\section{Human, socio-economic and cultural factors}

The competitive advantage of these local geomorphological and pedoclimatic conditions is further enhanced by the practices and know-how of the wine-growers, supported in turn by the cultural, educational, and scientific institutions that have shaped local wine-makers' skills, their culture, and their local identity. This has led to significant productive and technological innovations, even enhancing the quality of Prosecco wine.

The area's wine-growing process became more intense and specialized only towards the second half of the nineteenth century, perhaps also in response to the spread of several grapevine diseases (such as phylloxera, and downy and powdery mildew), which seriously damaged vineyards all over Europe.

In 1868, after the establishment of the Oenological Society in Conegliano, Prosecco wine starts getting attention. Earl Marco Giulio Balbi Valier, for instance, isolated and spread a specific biotype made of round berries in the area, later (and still today) known as Prosecco Balbi (Tomasi et al. 2013).

In 1876 the first Italian oenological school was established in Conegliano. The school contributed significantly to the progress of modern viticultural and oenological science - producing expertise, collective knowledge, and skills that were transferred

\footnotetext{
${ }^{7} \mathrm{~A}$ viticultural "terroir" (see Tomasi et al. 2013).
}

${ }^{8}$ The earliest documents on the cultivation of this vine varietal in the Veneto Region date back to Aureliano Acanti (1754) and Cosimo Villafranchi (1773) (Tomasi et al. 2013)

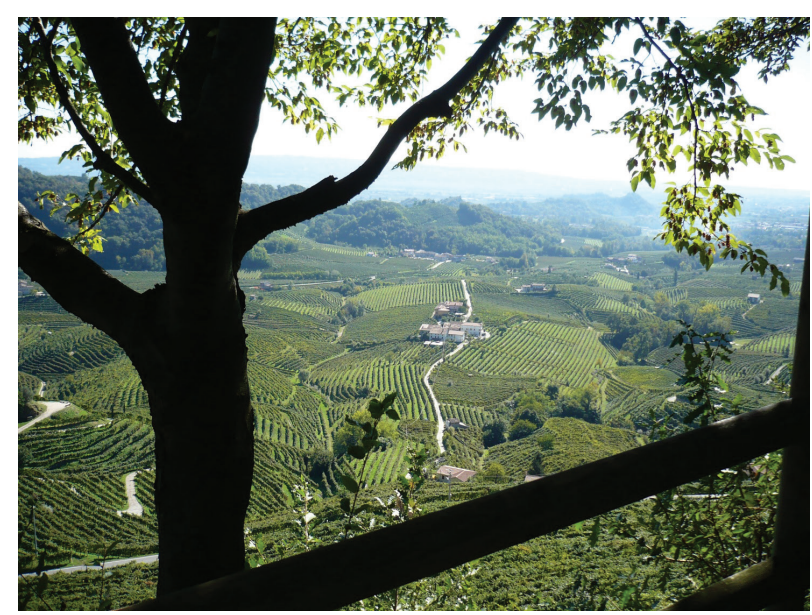

Figure 2. The Prosecco's hillside landscape. A historical equilibrium between man and nature

Source: photo taken by the author

directly to the territory and applied by wine-growers. Key figures who had extraordinary entrepreneurial and scientific roles include Antonio Carpenè, the co-founder of the school, who introduced and improved the production of Prosecco sparkling wine through a technique that conferred the distinctive organoleptic characteristics to the wine we know today. ${ }^{9}$ The first bottle of Prosecco sparkling wine was produced by the Carpenè Malvolti winery in 1924. The oenological school (today a technical high school institute) was followed in 1923 by the Istituto Sperimentale per la Viticultura (Experimental Institute for Viticulture; today a ministerial research centre) and, starting in 2000, the University of Padua established an interdepartmental research centre that specializes in viticulture and oenology.

Between the two world wars the area underwent a process of agricultural reorganization. In short, the promiscuous practices of viticulture of the past - which integrated sheep-breeding, cattlebreeding, silviculture, and the cultivation of other crops - were progressively abandoned in favour of specialized vineyards. During the period just after the Second World War and up until the seventies, the Glera grape was still a relatively little grown variety. But it soon imposed itself and finally replaced all the other local white vines. Compared to other varieties, the Glera grape was a rather vigorous vine particularly suited to sparkling wine production.

This grape variety was also strongly supported by the Confraternity of Valdobbiadene Prosecco, an association of young wine-makers, founded in 1946 that still exists today. The confraternity had a significant role in re-launching Prosecco and making the wine more appreciated (as well as other local wines) in an area that had been severely damaged during the Second World War and was characterized by intense emigration. ${ }^{10}$

\section{Public policies}

In the following years, as Prosecco started to establish itself on national and international markets, initiatives and public policies were being promoted by many actors. Between the sixties and late seventies, Prosecco's domestic market began to consolidate, albeit slowly. The number of wine-producers increased, driven by an endogenous process of imitation, as

${ }^{9}$ The so-called method of autoclaving refermentation, later enhanced by Carpene's grandchildren.

${ }^{10} \mathrm{~A}$ real market for Prosecco wine did not exist at that time. A common practice was to exchange (a sort of barter) this wine with flour produced on the plains. 
did the amount of surface area that was planted with the Glera grape variety. In 1962, to protect and enhance the product, eleven local producers created the Consorzio di Tutela (a consortium that protects the wine) and, in 1969, the Prosecco Denomination of Controlled Origin (DOC in Italian) was formally established. This area was then designated as a "superior zone" in 2009 (the status of Denomination of Guaranteed and Controlled Origin-DOCG), and thus a step up in terms of quality recognition.

The most significant territorial promotion policies included the creation of the first Italian white wine route in 1966 (Strada del vino bianco, known today as Strada del Prosecco), and the many wine exhibitions organized by local associations (the first one was back in 1934). In the wake of Prosecco's economic and commercial success, its international reputation, which had begun in the eighties and nineties, was finally consolidated during the last decade. There was also the attribution (to the entire Conegliano Valdobbiadene DOCG territory, and not just to a single city) of the title of European Wine City for 2016, as well as the recent candidacy of the Prosecco Hills as a UNESCO World Heritage Site.

In addition to other promotional efforts, for instance, being featured in an Italian film that was released in fall $2017,,^{11}$ Prosecco's success has also been massively supported - starting in the eighties - by important EU financial contributions that are aimed at restructuring and reconverting existing vineyards, as well as planting new ones.

\section{Evolution: territorial "proseccosization"}

The global economic and commercial success of Prosecco wine and its winescape, as was seen in section 4, is the result of a long-term social construction process. In recent years, Prosecco has become the most popular Italian sparkling wine on global markets, and whose demand has increased both nationally and internationally. Its strong performance in the market has replaced - even in terms of employment rates - certain traditional industries affected by the recent economic crisis. ${ }^{12}$

Of the two hillside DOCG zones (Conegliano Valdobbiadene and Asolo), the former is the most significant in terms of viticulture and wine-making tradition and culture, but also in terms of amount of vineyard land, number of wine-growers, and annual wine production and commercialization. ${ }^{13}$

According to the 2017 annual economic report by the district's research centre (Research Centre of the Conegliano Valdobbiadene District 2017), between 2003 and 2016 production increased by $129 \%$, with 90.4 million bottles of wine on the market in 2016. In the 2015-2016 period, it experienced a further $8 \%$ increase in volume and $11 \%$ increase in value. Sparkling wine exports registered a remarkable $234 \%$ growth between 2003 and 2015. Alongside traditional European destinations such as Germany, Switzerland, and Austria, exports to the UK surged in particular, with an increase in bottle exports of more than $1173 \%$ between 2003 and 2016; and in Scandinavia the figure was $+446 \%$. In reference to nonEuropean countries, the largest export markets between 2003 and 2015 were Australia and New Zealand $(+1022 \%)$, the US $(+283 \%)$, and Canada (+244\%).

Thanks to an ever-expanding market demand, EU public funding for the planting of new vineyards, and an administrative

${ }^{11}$ Finchè c'è Prosecco c'è speranza by Antonio Padovan, a film adaptation of Fulvio Ervas' detective story, which was set in the Prosecco Hills.

${ }^{12}$ Thus wine and other agro-food products have become one of the most strategic products in the regional economy. Veneto ranks among Italy's most productive wine regions, confirming its leadership in wine exports (Veneto Region 2017).

${ }^{13}$ Accordingly, Regional Law 8/2003 designated the area as an agro-food economic district with a historical specialization in the production of sparkling wine. reform of Prosecco's Denominations of Origin, vineyard cultivation has greatly expanded in the Prosecco region in the last decade, and is still an ongoing phenomenon today. In fact, when considering the fast growing interest in this wine abroad, in 2009 Luca Zaia - the Italian Minister for Agricultural, Food and Forestry Policies at the time - expanded the area of wine producing land from the small hillside areas of Conegliano Valdobbiadene and Asolo, to a much larger territory that comprised of nine provinces in the Veneto and the Friuli-Venezia Giulia Regions. The latter was granted the status of a DOC zone, and the former obtained DOCG status.

Consequently, the expansion of new vineyards is now a widespread trend, being an economically viable operation not only in the hills but especially on the plains, where truly remarkable land-use changes have been triggered. Since the historical Conegliano Valdobbiadene DOCG area is currently highly "saturated" in terms of land availability for the wine industry, its neighbouring edges, which include Asolo DOCG and the wider Prosecco DOC territory, are being "colonized". Given the geomorphological conditions of the DOC zone (a predominantly flat terrain), agricultural machinery and modern wine-growing practices have become widespread, and are critically affecting biodiversity and the complexity of the territory by replacing hedges, trees, headlands and ditches with a "uniform" landscape made mostly of large plots of land and regular geometric shapes ${ }^{14}$ (Fig. 3). "Proseccosization" dynamics, I argue, are thus radically changing Veneto's landscape and progressively transforming traditional cropland, grassland, and woodland into vineyards that are producing Prosecco.

Land-use changes in the Conegliano Valdobbiadene DOCG municipalities

According to the Veneto Region Land Cover Map (Veneto Region 2015), some $8,883.80$ ha of vineyards were recognized in 2012 as being within the 15 municipalities wholly or partly located within the Conegliano Valdobbiadene DOCG area, that is, $47.84 \%$ of the total agricultural area. Such incidences are higher in the hills surrounding the small towns whose name reflects the wine Denomination of Origin (Valdobbiadene in the west and Conegliano in the east). On December 1, 2016, according to the Veneto Region and Avepa's Venetian Vineyard Register (Veneto Region \& Avepa, 2016), the amount of surface that is planted with the

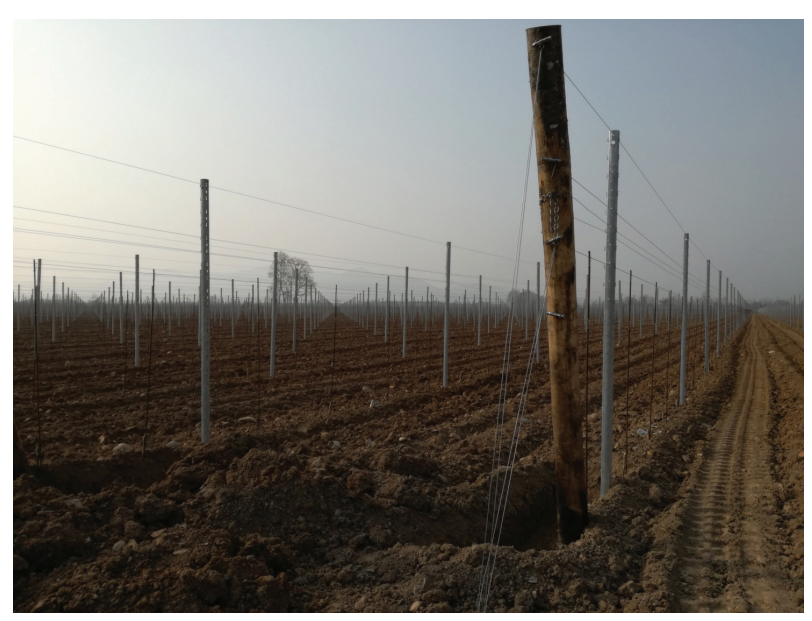

Figure 3. The Prosecco landscape on the plain: large geometric vineyards perfectly suited to agricultural machinery Source: photo taken by the author

${ }^{14}$ This dynamic also changes the chemical-physical structure and quality of the soil. 


\section{Municipal borders}

Institutional border of the Conegliano Valdobbiadene DOCG Prosecco zone

New vineyards planted between 2007 and 2012

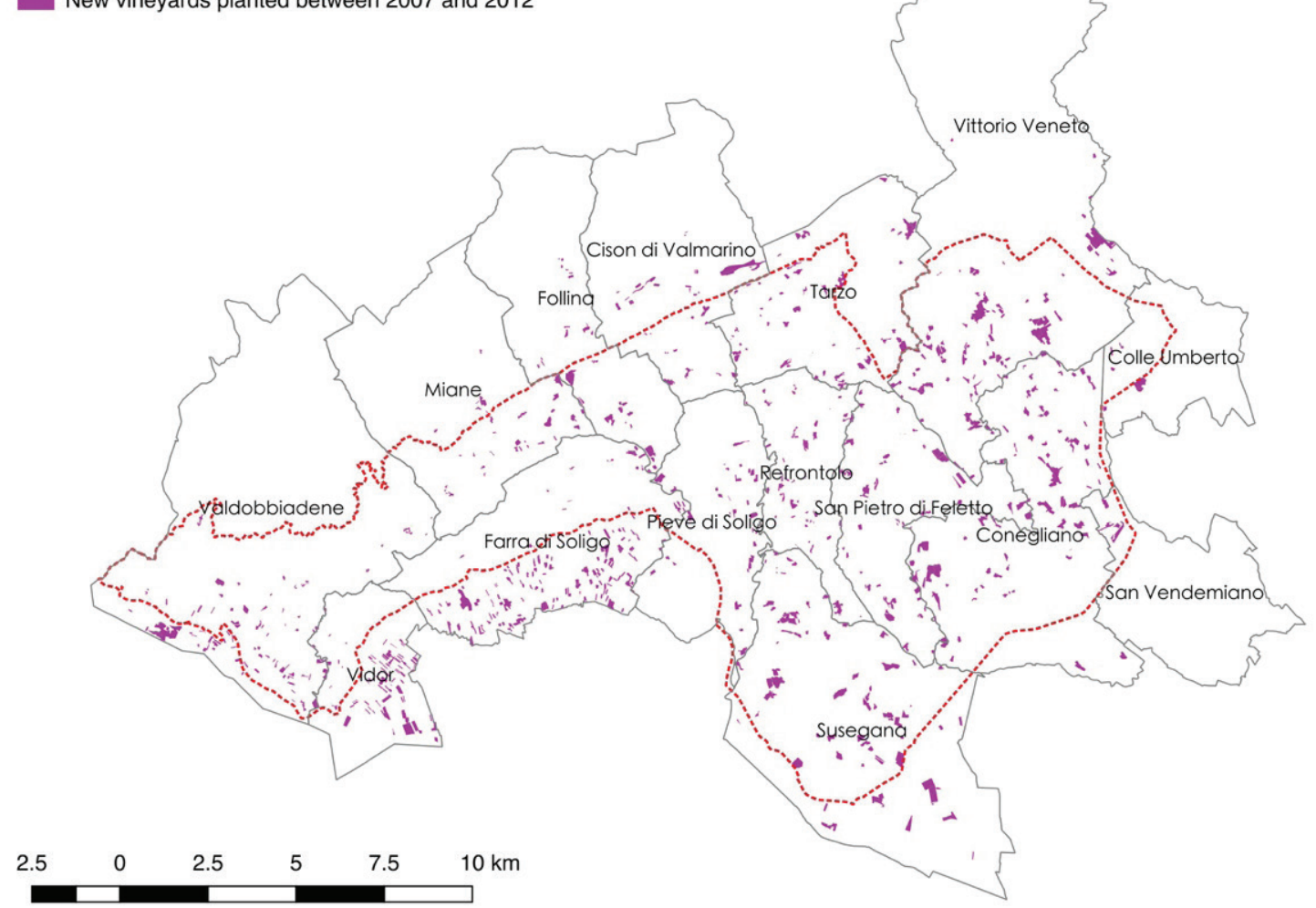

Figure 4. New vineyards planted between 2007 and 2012 - Conegliano Valdobbiadene DOCG Prosecco zone (15 municipalities). Source: author's elaboration on Veneto Region (2009; 2015) ${ }^{15}$

Glera grape variety - the main grape variety in Prosecco wine - covered 6,768.30 ha of the entire DOCG institutional territory.

In just five years (2007-2012), the amount of land for winegrowing increased by $12.31 \%$, mostly in areas located in the north-eastern part of the territory at the foothills of the Alps (Veneto Region 2009; 2015). Specifically, new vineyards planted in the territory between 2007 and 2012 cover $1,063.86$ ha of land. Out of this, $63.11 \%$ of cropland had been converted to new vineyards (671.39 ha), followed by grassland $(32.91 \%, 350.09 \mathrm{ha})$, woodland $(2.55 \%, 27.12 \mathrm{ha})$, and urbanized areas $(1.43 \%, 15.26$ ha) (Fig. 4). Figure 5 describes the main land-use changes (for types of land-use: cropland, vineyards, grassland, and woodland) that occurred in the area between 2007 and 2012. As is evident, the cropland and grassland is highlighted by a decrease of $13 \%$ and $6 \%$ respectively, while woodland remained almost stable (however with a slight decrease: $-0.30 \%$ ). In contrast, vineyards registered a significant $12 \%$ increase in just five years.

As highlighted in Figure 4, most of these land-use changes affected areas of the DOCG zone in municipalities such as Vittorio Veneto and Conegliano. In contrast, starting in 2009, modifications in Farra di Soligo, Susegana, Vidor, and Valdobbiadene involved areas belonging mostly to the DOC zone. This provides empirical evidence for the colonization process that has swept this land bordering the historical Prosecco production area.

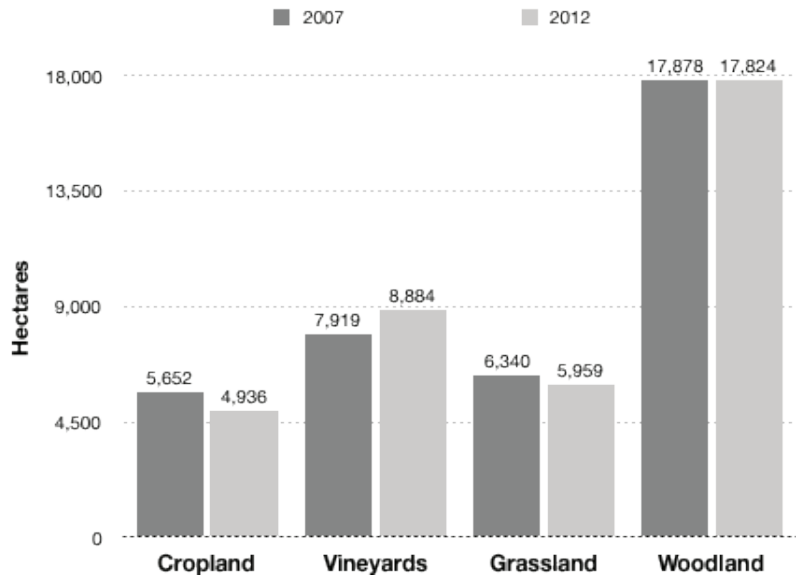

Figure 5. Land-use changes that occurred between 2007 and 2012 - Conegliano Valdobbiadene DOCG Prosecco zone (15 municipalities)

Source: author's elaboration on Veneto Region (2009; 2015)

${ }^{15}$ The municipal territory falling outside of the DOCG institutional boundary belongs to the Prosecco DOC zone, which was established in 2009 
Based on the Venetian Vineyard Register (Veneto Region \& Avepa 2016), the cultivation of the Glera grape variety, driven by the availability of land, has progressively expanded - starting in the sixties and particularly in the seventies - from the historical core production area of Valdobbiadene in the west towards the eastern part of the DOCG area, initially reaching the town of Conegliano and then stretching up onto the hills of Vittorio Veneto in the north. Today, as already stated, it has definitely crossed the DOCG's boundaries. Powerful economic investors coming from the nearby saturated Conegliano Valdobbiadene zone often plant new vineyards in the 17 neighbouring municipalities belonging to the DOCG Asolo zone, where vine density is still moderate (only a $11.52 \%$ incidence in the total agricultural area), and in the wider DOC zone.

Conclusions: what future awaits the Prosecco winescape?

This paper has briefly traced the origins and recent evolution of a specific viticultural landscape in Italy, based both on qualitative and quantitative methods.

As previously illustrated, progressive land saturation has affected the historical production zone - the hillside vineyards of the Conegliano Valdobbiadene DOCG - with consequent new vines planted in the neighbouring and less dense Asolo DOCG, but especially on the plains of the DOC territory, which was expressly established in 2009 . The remarkable landscape changes in the latter have led to a progressive decline in cropland, grassland, and woodland - almost on a daily basis, and often generating heated public debate - and to new surfaces planted with Prosecco's main grape, the Glera. Significant public incentives for wine-growers have also contributed to this phenomenon.

To reduce production costs and increase profitability, investments in new vineyard locations are radically changing the local landscape. Except for steep hilly slopes (where winegrowing compels - as it always has - manual labour), the modern machinery used on the plains has almost turned it into a monoculture and an area of uniform landscapes. Large geometric vineyards are planted without respecting the traditional biodiversity of the territories (i.e., landscape elements such as hedges, rows of trees, and ditches), or vine plantation and cultivation techniques (i.e., pairing the grapevine to a living prop such as a tree, instead of the concrete or iron poles used nowadays).

A growing network of environmental organizations, committees, associations and, in particular, small spontaneous groups of citizens, are speaking out more and more often on the geomorphological modifications of the hills, the hydrogeological risks connected with the expansion of vineyards, and the impacts of chemical products on public health and on the environment (Fig. 6).

What is needed in the future for the entire Prosecco region - considering that the Conegliano Valdobbiadene DOCG area is a candidate for a UNESCO World Heritage Site - is proper

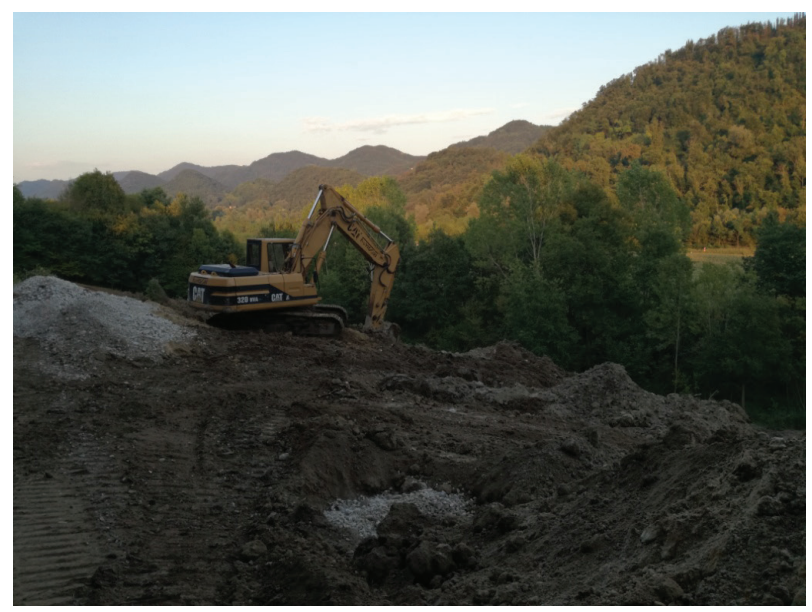

Figure 6. Geomorphological modifications to the hills for the planting of new vineyards in the Asolo DOCG zone. Source: photo taken by the author

rules and management of such an intensive, market-driven monoculture. In addition, an inter-municipal territorial policy is needed to effectively harmonize (as in the past) the production needs of wine-growers with other land-uses (mostly residential), and to protect the historical landscape patterns and ecological biodiversity.

Triggered by several territorial conflicts, an institutional response to the increasing impacts of wine-growing has started to emerge, albeit slowly. Local governments and representatives of the entire wine industry - as emerged during the interviews with policy-makers - are progressively adopting or revising more restrictive policy tools to regulate the planting of new vineyards and their production techniques. For a more environmental and landscape "friendly" viticulture, however, such tools are not fully sufficient. Creating a greater awareness, in tandem with educating wine-growers and all the other actors operating in the wine sector, to adopt alternative and more sustainable production methods ought to be the starting point ${ }^{16}$. Furthermore, as the distances between vineyards and residential buildings, and the timing and mode of chemical spraying with pesticides are currently defined by sectorial policy tools such as the regolamenti di polizia rurale (rural police regulations), a recommendation would be to tackle the issue of new vineyard plantations within the ordinary territorial and urban planning schemes, so as to effectively integrate sectorial decisions of land-use into the general strategies of regional development and protection.

${ }^{16}$ Obviously, it needs the support of ad hoc public incentives that encourage an organic farming method to produce wine.

\section{References}

Braudel, F 1958, 'Histoire et sciences sociales. La longue durée', Annales. Économies, Sociétés, Civilisations, $13^{\mathrm{e}}$ année, no. 4, pp. 725-753.

Costantini, EAC \& Barbetti, R 2008, 'Environmental and visual impact analysis of viticulture and olive tree cultivation in the province of Siena (Italy)', European Journal of Agronomy, vol. 28(3), pp. 412-426.

Dobos, A, Nagy, R \& Molek, A 2014, 'Land use changes in a historic wine region and their connections with optimal landuse: a case study of Nagy-Eged Hill, Nothern Hungary',

Carpathian Journal of Earth and Environmental Sciences, vol. 9(2), pp. 219-230.

European Landscape Convention of the Council of Europe, 2000. Available from: <https://rm.coe.int/1680080621> Access date December 4, 2017.

Fairbanks, DHK, Hughes, CJ \& Turpie, JK 2004, 'Potential impact of viticulture expansion on habitat types in the Cape Floristic Region, South Africa', Biodiversity \& Conservation, vol. 13(6), pp. 1075-1100. 
Martínez-Casasnovas, JA, Concepción Ramos, M \& Cots-Folch, R 2010, 'Influence of the EU CAP on terrain morphology and vineyard cultivation in the Priorat region of NE Spain', LandUse Policy, vol. 27(1), pp. 11-21.

Merenlender, AM 2000, 'Mapping vineyard expansion provides information on agriculture and the environment', California Agriculture, vol. 54(3), pp. 7-12.

Mariani, A \& Vastola, A 2015, 'Sustainable winegrowing: current perspectives', International Journal of Wine Research, vol. 7, pp. 37-48.

Ministerial Decree of 17 July 2009, Riconoscimento della denominazione di origine controllata dei vini «Prosecco», riconoscimento della denominazione di origine controllata e garantita dei vini «Conegliano Valdobbiadene - Prosecco» e riconoscimento della denominazione di origine controllata e garantita dei vini "Colli Asolani - Prosecco» o "Asolo Prosecco» per le rispettive sottozone e approvazione dei relativi disciplinari di produzione. Available from: <http://www.gazzettaufficiale.it/eli/id/2009/07/28/09A08700/ sg>. Access date November 15, 2017.

Research Centre of the Conegliano Valdobbiadene District 2017, Rapporto annuale 2017 (annual report 2017). Available from: <http://www.prosecco.it/it/consorzio/chi-siamo/\#>. Access date December 1, 2017.

Tomasi, D, Gaiotti, F \& Jones, GV 2013, The power of the terroir: the case study of Prosecco wine, Basel [etc.]: Springer.

Veneto Region 2009, Banca Dati della Carta della Copertura dell'uso del suolo edizione 2007 (Dataset of the Land Cover Map 2007 edition). Available from: <http://idt.regione. veneto. it/app/metacatalog/index?deflevel $=165>$. Access date October 7, 2016.
Veneto Region 2015, Banca Dati della Carta della Copertura dell'uso del suolo edizione 2012 (Dataset of the Land Cover Map 2012 edition). Available from: <http://idt. regione.veneto.it/app/metacatalog/index?deflevel=165>. Access date October 7, 2016.

Veneto Region 2017, Rapporto statistico 2017 (Statistical report 2017). Available from: <http://statistica.regione.veneto.it/ pubblicazioni_convegni_ultimo.jsp>. Access date December 1, 2017.

Veneto Region Law April 4, 2003, no. 8, disciplina delle aggregazioni di filiera, dei distretti produttivi ed interventi di sviluppo industriale e produttivo locale. Available from: <http:// www.consiglioveneto.it/crvportal/leggi/2003/03/r0008.html>. Access date November 15, 2017.

Veneto Region \& Avepa 2016, Schedario Viticolo Veneto, aggiornato al 1 Dicembre 2016 (Venetian Vineyard Register, last update December 1, 2016). Dataset provided by Avepa.

Vinatier, F \& González Arnaiz, A 2018, 'Using high-resolution multitemporal imagery to highlight severe land management changes in Mediterranean vineyards', Applied Geography, vol. 90, pp. 115-122.

Zambon, I, Colantoni, A, Cecchini, M \& Mosconi, EM 2018, 'Rethinking sustainability within the viticulture realities integrating economy, landscape and energy', Sustainability, vol. $10(2)$, p. 320. 